\title{
Noble Lineage as a Response to Enslavement in the Testament of Naphtali 1.9-12 1
}

\author{
JOHN BYRON \\ Ashland Theological Seminary, Ashland, Ohio
}

$\mathrm{T}$ he Testament of Naphtali is the purported last words of the patriarch identified in Genesis 30:8 as the son of Jacob and Bilhah. The Testament contains many of the expected elements of this genre including: the gathering of family at the time of the patriarch's death to hear a review of the patriarch's life through a mixture of canonical and apocryphal events which are interspersed with final instructions/warnings about living in righteousness. One aspect that is shared by many but not all of the documents contained in the corpus of The Testaments of the Twelve Patriarchs is a description concerning the particulars of each patriarch's birth. ${ }^{2}$ Three of the Testaments simply identify both parents and the order in which the son was born. ${ }^{3}$ The $T$. Issachar describes the patriarch's birth through a reworking of the canonical mandrakes story in Genesis 30:14-19. The T. Benjamin, on the other hand, provides an apocryphal description of a miraculous birth after a long period of barrenness while the T. Levi merely notes the location of the patriarch's birth as Haran. The T. Naphtali is unique, however, because it is the only Testament that provides a lineage for the patriarch beyond that of the parents. The presence of this lineage has usually been viewed as an addition that provided the concubine Bilhah with Semitic descent ${ }^{4}$ and positioned her offspring in the Abraham-Isaac-Jacob line thus guaranteeing them a place in the destiny of the nation. ${ }^{5}$ While this is undoubtedly the case, this paper will demonstrate that the lineage is also the result of tensions concerning sexual relationships between patriarchs and slaves and the symbolic problems associ-

1 This paper was first presented in November 2001 at the annual meeting of the Society of Biblical Literature in Denver, Colorado. Special thanks are offered to Professor C. T. R. Hayward who read another version of this paper and offered some important insights.

2 There is a considerable debate as to whether T. 12 Patr. are of Jewish or Christian origin. These questions have no direct relevance to the genealogy of Bilhah, however. The occurrence of a similar genealogy in the Qumran fragment 4Q215 (discussed below) suggests that an older textual tradition is at work here (See DJD 22:73-82). Th. Kortweg has convincingly demonstrated that the author of Greek T. Naphtali revised this earlier Hebrew tradition. Thus, while some scholars have concluded that much of the Testament is Christian in origin, it is generally accepted that the Bilhah genealogy represents an earlier tradition ('The Meaning of Naphtali's Visions' in Studies on the Testaments of the Twelve Patriarchs, ed. M. De Jonge, Leiden: E.J. Brill, 1975, 261-90). For a survey of the debate concerning the origins of the Testaments as well as brief discussion of the genealogy see Robert A. Kugler The Testaments of the Twelve Patriarchs (Guides to the Apocrypha and Pseudepigrapha), ed. Michael A. Knibb (Sheffield Academic Press, 2001), 2539, 71-72.

3 T. Judah 1.3; T. Zebulon 1.3; T. Gad 1.2.

${ }^{4}$ R. H. Charles, 'The Testament of Naphtali', in The Apocrypha and Pseudepigrapha of the Old Testament (Oxford: Clarendon Press, 1966), vol. 2, p. 336.

5 H. C. Kee, 'Testaments of the Twelve Patriarchs', in The Old Testament Pseudepigrapha, ed. J. H. Charlesworth (NY, Doubleday: 1983), vol. 1, p. 811. 
ated with offspring produced by these relationships. Some post-biblical interpreters expressed reservations about the identification of Leah and Rachel's handmaids, Zilpah and Bilhah ( $\pi \propto \iota \delta i \sigma \kappa \eta)$, as the mothers of four of the tribes of Israel (Gad, Asher, Dan, Naphtali). It is my contention that the lineage represents more than just a way to provide a concubine with Semitic background; it was a way to legitimise offspring produced with a slave. This can be demonstrated by placing T. Naphtali into the wider context of post-biblical literature. This will not only reveal the resentment that some held towards those they considered to be the 'sons of slaves', but also the ingenious way that the Testament's author solved this identification problem.

\section{Post-Biblical Attitudes towards the Children of Zilpah and Bilhah}

In Greek T. Naphtali 1.9-12, the fabricated lineage is traced back to the tribe of Abraham in Chaldea through a fictitious ancestor named Rotheos. ${ }^{6}$ The writer asserts that Rotheos, one who honoured God and was free and nobly

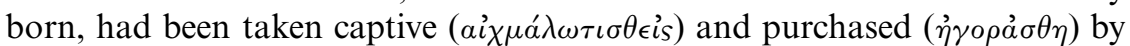
Laban who in turn gave to him Aina, a slave girl ( $\pi \iota \alpha \delta i \sigma \kappa \eta)$, as a wife. Aina subsequently bore two daughters, Zilpah ${ }^{7}$ and Bilhah, who later became the mothers of four patriarchs. ${ }^{8}$ That there is no mention of any sons that Rotheos and Aina may have produced suggests that the author's purpose of the lineage was only to legitimise the ancestry of the handmaid's children and no one else. ${ }^{9}$ The positioning of the lineage in the passage follows the description of Joseph as the son of Rachel (1:8). By inserting the lineage here, the author is able to claim equal status between Joseph and Naphtali by declaring that apart from the identification of their mothers they were in all ways alike. ${ }^{10}$ The fact, then, that Rotheos and his daughters are in a situation of enslavement under Laban becomes irrelevant in light of their true status, which is an ancestry through Abraham that has been interfered with by an unjust captivity/enslavement. By creating the lineage, the author avoided the implicit classification that Naphtali and his brothers were the 'sons of a slave'. ${ }^{11}$ Moreover, Jacob is no longer portrayed as producing offspring with slaves, but with distant relatives from his own family.

${ }^{6}$ All quotes from T. Naphtali are taken from M. de Jonge, The Testament of the Twelve Patriarchs: A Critical Edition of the Greek Text, with H. W. Hollander, H. J. de Jonge and Th. Korteweg (Pseudepigrapha Veteris Testamenti Graece 1.2, Leiden, 1978), and Albert-Marie Denis, Concordance grecque des pseudepigraphes d'Ancien Testament (Louvain ] la-Neuve: Université Catholique de Louvain, Institut orentaliste, 1987), p. 844.

7 The author claims that Zilpah received her name from the village in which Rotheos had been taken captive (T.Naph. 1.11).

8 Jubilees 28:9 also claims that Zilpah and Bilhah were sisters.

9 Apparently the status of Aina, Rotheos' wife, as a slave did not concern the author. What was important was that it could be demonstrated that Naphtali and his three brothers had parents from the lineage of Abraham on both sides.

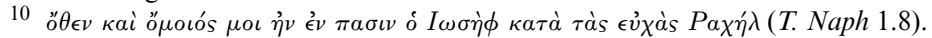

11 Hints of conflict between the children of the four mothers can be found in the Genesis account, which portrays Joseph as presenting a negative report to his father concerning the sons of Zilpah and Bilhah (Gen. 37:2). 
The Qumran fragment 4Q215 (4QTNaphtali) also includes a genealogy for Bilhah, but it is somewhat different from Greek T. Naphtali. ${ }^{12}$ Here, in what remains of the fragmented text, Bilhah's father is not named Rotheos but Ahiyot, and missing is any mention that he was from the same tribe as Abraham in Chaldea. ${ }^{13}$ Similar to Greek T. Naphtali, it says that he went into captivity, but rather than describing Laban as purchasing Ahiyot as a slave,

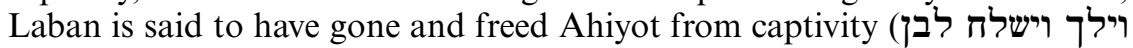
and gave to him his own maidservant Hannah who bore him Zilpah and Bilhah (ויתן את חנה). Even with these differences, however, the same intention is evident in both the Greek and Hebrew versions of the lineage. The status of Rachel and Leah's handmaids was not one of birth in enslavement and consequently neither was it for the four sons they bore their mistresses. This approach to the problem may be an attempt by the fragment's author to remove the stain of slavery from Naphtali and his brothers by not leaving their grandfather in a perpetual state of enslavement to Laban. Instead the author opted to present enslavement as merely an unfortunate and thus unjust event. Whatever the reason, the results of the lineage in the Qumran fragment are the same as Greek T. Naphtali; the offspring of the handmaids could not be legitimately identified as the sons of slaves. ${ }^{14}$

Joseph and Aseneth is familiar with the problems surrounding the status of the handmaids' children and uses this as the basis of an attack by the four brothers against Aseneth. In 24:7-10, the Pharaoh's son enlists Gad, Asher, Dan and Naphtali in a plan that will fulfill both his political and romantic ambitions. In order to convince the sons of Zilpah and Bilhah to help him, he fabricates a conversation overheard between Joseph and Pharaoh in which Joseph declares his intention to murder the four patriarchs after Jacob's death as revenge for their selling him to the Ishmaelites. The reason for the decision to punish these four and not the other brothers is that they are the sons of

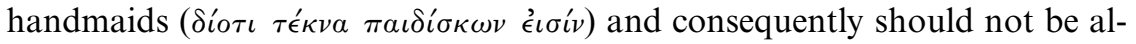
lowed to share in the inheritance of Jacob with the other eight brothers. Here, unlike T. Naphtali, the author does not avoid the status of the handmaids' children, but instead seems to be using a historical tension between the sons of the various mothers. Readers of Joseph and Aseneth may have been familiar with accusations that those who descended from these women were not from the pure line of Israel and thus held a secondary status as the sons of slaves.

Josephus also attempts to get around the status of the handmaids. In $A n$ tiquities 1.303, he recounts the giving of the handmaids in Genesis 30, but is careful to differentiate for the reader that although they are handmaids $(\theta \epsilon \rho \alpha-$

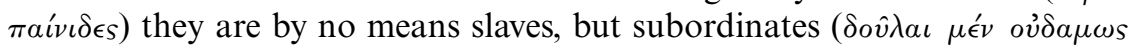

12 M. E. Stone, 'The Genealogy of Bilhah', $D S D 3$ (1996), pp. 20-36; 'Testament of Naphtali', JJS 47 (1996), pp. 311-21. Codex Oxford d11 (the chronicle of Jerahmeel) also contains a Hebrew T. Naph., but not a Genealogy (Stone, 23).

13 Stone has compared the fragment to similar material found in Midrashic writings Berešit rabbati $[\mathrm{Brab}]$ associated with $\mathrm{R}$. Moses the Preacher from Narbon in the eleventh century (23, 31).

14 Stone notes that the Qumran fragment demonstrates the existence of a Naphtali tradition in the Second Temple Period. 


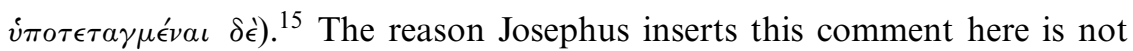
clear, but this section does follow an earlier discussion in 1.187-88, 215216, describing how Sarah feared that Ishmael, as the eldest son of Abraham, would, upon his father's death, become heir and attempt to harm Isaac. Josephus may be trying to differentiate for his readers the difference between the status of the handmaid Hagar whose son had no inheritance in Israel $(\theta \epsilon \rho a \pi \alpha \iota \nu \iota \delta \omega \nu \dot{a} \gamma \alpha \rho \eta \nu)$ from that of Zilpah and Bilhah who gave birth to legitimate heirs.

Josephus also exhibits reservations about the practice of sexual relations with slaves. In Antiquities 3.276, slaves are added to the list of women from Leviticus 21:7-14 that priests are forbidden to marry. Josephus seems to interpret the fear of pollution and the regulation of marrying within the family as a disqualification of slaves. ${ }^{16}$ In Against Apion 1.35, the restriction is repeated with the added explanation that it is assumed that female slaves probably had frequent intercourse with foreigners. ${ }^{17}$ The seriousness of this regulation is emphasised by two recorded instances in Josephus showing that descent from a slave or captive was used as an accusation, albeit false, in an attempt to disqualify two different Hasmonean High Priests. ${ }^{18}$

Josephus does not stop, however, in applying the restrictions to the priestly population only. Laity should also follow this restriction by not allowing freemen to take female slaves into marriage regardless of how strong the bond of love. Such passions are to be mastered and put aside in consideration of what is suitable ( $\left.\pi \rho \sigma_{\sigma} \sigma \phi \rho \rho o v\right)$, honourable $(\alpha \xi \iota \dot{\omega} \mu \alpha \sigma \iota)$ and befits a good outward appearance ( $\epsilon \dot{v} \pi \rho \pi \epsilon^{\prime}$, Ant. 4.244). ${ }^{19}$ Josephus ranks the slave in the same category as the prostitute and seems to assume that they are of foreign rather than Jewish origin. Any attempt to introduce a slave into a marriage was to bring a disgrace upon the Jewish freeman and presumably his people.

Bias against the four brothers can also be detected in the works of Philo of Alexandria. ${ }^{20}$ Philo regularly describes Zilpah and Bilhah as handmaids, but his portrayals of the sons and the matter of wider family relationships are inconsistent. ${ }^{21}$ For example, Philo describes Issachar as Jacobs's fifth legiti-

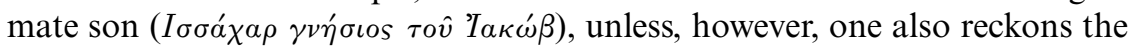

15 All quotations from Josephus are taken from H. St. J. Thackeray et al. (eds.), Josephus (10 vols; LCL; Cambridge, MS and London: Harvard University Press and Heinmann, 1926-1965).

${ }^{16}$ H. St. J. Thackeray, 'Josephus: Jewish Antiquities', Loeb Classical Library (Cambridge: Harvard University Press, 1926-1965), vol. 4, p. 93.

17 Josephus is in agreement with b. Yeb. 61a which forbids priests to marry slaves because they may have had intercourse with Idolaters.

18 In Antiquities 13.292 and 372 both John Hyrcanus and Alexander Jannaeus are accused of having been descended from captives and thus unfit to serve as High Priest. Josephus notes that this was not only a baseless charge but was also an incredible insult.

19 This is admittedly a strange thing for Josephus to say considering he admits to having married a captive at Caesarea. He says that the woman was an inhabitant of the country and thus presumably a Jew, which could explain any apparent contradiction. The fact that he records he later divorced her may reflect upon his later opinion concerning such arrangements (Life, 75).

20 All quotations of Philo are taken from F. H. Colson, G. H. Whitaker, R. Markus et al., Philo (10 vols and 2 supplementary vols; LCL; Cambridge, MA: Harvard University Press, 1929-1962).

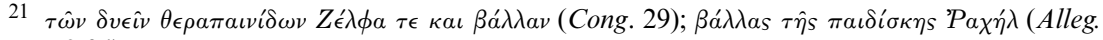
Interp. 2.94). 
sons of Zilpah then he is the seventh. ${ }^{22}$ Zilpah and Bilhah are described as Jacob's wives, but their children are not considered to be legitimate ( $\gamma \nu \eta \sigma i o v$ ) but bastard brothers ( $\nu o^{\prime} \theta \omega \nu \quad \alpha \delta \epsilon \lambda \phi \omega^{\prime} \nu$ ), the sons of concubines and, as Philo carefully points out, called the children of their mothers but not their father (Unchangeable, 199-121). ${ }^{23}$

In the work on the Virtues (223-225), however, the situation is completely changed. Here we are led to believe that Zilpah and Bilhah ceased to be handmaids when they became Jacob's wives and that they gained equal status with

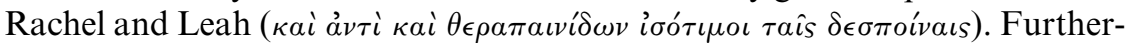
more, it is claimed that the children of these women were not hated or treated as step-relations, but were loved by the others and all joined together into a single harmonious family.

These interpretations are not restricted to writers of the Second Temple period only, but extend into later literature as well. In Genesis Rabbah it is claimed that Zilpah and Bilhah were Laban's daughters through a concubine and that Joseph despised their children because they were 'the sons of slaves' (GenR. 37.2). ${ }^{24}$ Exodus Rabbah notes that in the scriptures the tribes of Israel are often presented in various orders. The suggested answer is that this was to prevent anyone from putting the children of the wives before the handmaids, probably a recognition of the propensity for this to happen $(E x R .1 .6)$.

Targum Pseudo-Jonathan is careful to describe the role of concubines in such a way that children produced through a union of patriarch and slave are not given the status of slaves. In 16. 2-5, Sarah is said to have freed her handmaid Hagar before giving her to Abraham. Similarly, Zilpah and Bilhah are freed from their servile position before being handed over to Jacob for the purposes of producing offspring $(30.4,11) .{ }^{25}$ By presenting the situation of patriarch/slave copulation in this manner, the writer ensures that all of the children of Israel are recognised as legitimate and not under the stigma of being born as the sons of slaves.

The Mishnah does not exhibit any particular reservations about Zilpah and Bilhah, but it does provide some important insights. In Kiddushin 3.12, it is ruled that the offspring of a female slave follows the societal status of the woman. Thus, if an Israelite male conceives with a slave, the offspring is recognised as a slave because the relationship was invalid based on the woman's status. ${ }^{26} \mathrm{P}$. V. M. Flesher comments on this passage:

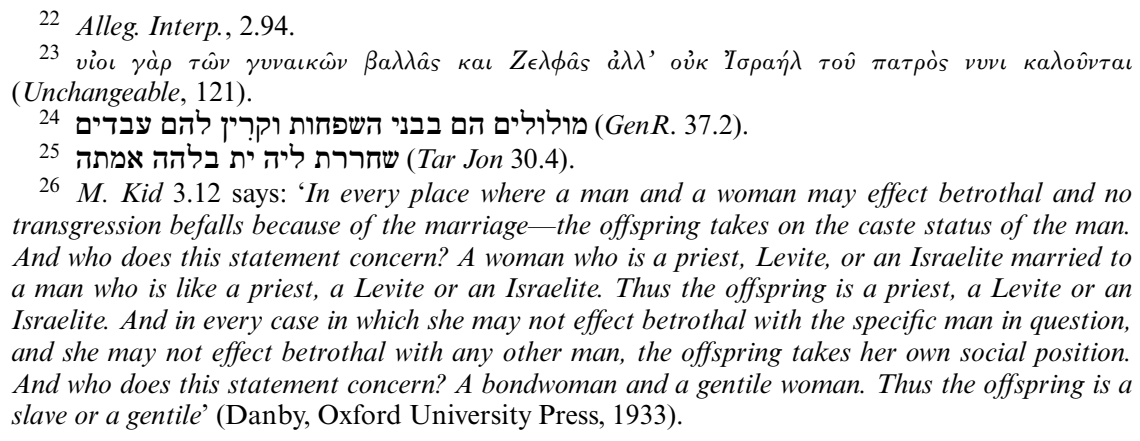

26 M. Kid 3.12 says: 'In every place where a man and a woman may effect betrothal and no transgression befalls because of the marriage - the offspring takes on the caste status of the man. And who does this statement concern? A woman who is a priest, Levite, or an Israelite married to a man who is like a priest, a Levite or an Israelite. Thus the offspring is a priest, a Levite or an Israelite. And in every case in which she may not effect betrothal with the specific man in question, and she may not effect betrothal with any other man, the offspring takes her own social position. And who does this statement concern? A bondwoman and a gentile woman. Thus the offspring is a slave or a gentile' (Danby, Oxford University Press, 1933). 
[T]he Bondwoman deprives the man of his ability to control his offspring's status, she clearly possesses the capacity to dictate her children's status ... [It] reveals that bondwomen cannot enter a permitted sexual union with an Israelite male ... Since she cannot become betrothed, she cannot be party to a legally recognised marriage and no slave can form kinship ties of any sort - a necessary prerequisite of a valid marriage. Thus, in the Mishnah, the bondwoman has no capacity to form a legal marriage and cannot form a valid kinship tie with her sex partner. ${ }^{27}$

If the Mishnah reflects upon earlier held principles in Jewish society, and the efforts of some to expunge evidence of patriarch/slave copulation suggests that it does, then any hint of a patriarch having intercourse with, or descended from, a slave would nullify claims of kinship by either the slave or their offspring. The halkhahic ruling would have threatened the status of Zilpah and Bilhah's children and explains why editorial efforts were attempted to legitimise four of the tribes of Israel.

\section{Noble Birth as a Status Contrary to Slavery}

Returning to Greek T. Naphtali, an important statement is made in conjunction with the fictional ancestor Rotheos that requires further examination. In 1.10 the author claims that Rotheos was from the same Chaldean tribe as Abraham, that he honoured God $(\theta \epsilon \sigma \sigma \epsilon \beta \dot{\eta} s)$, was free $(\epsilon \lambda \epsilon \dot{v} \theta \epsilon \rho o s)$ and of noble birth $(\epsilon \dot{v} \gamma \epsilon \nu \eta \dot{\eta})$. Immediately following this statement is a description in 1.11 of Rotheos' captivity and subsequent sale to Laban. The structure of the passage suggests a contrast between Rotheos' status as a God-honouring, free and nobly born Chaldean with his unjust captivity/enslavement. In particular, I believe that the notion of Rotheos' noble birth $(\epsilon \dot{v} \gamma \in \dot{\epsilon} v \epsilon \iota a)$ presents a clear reason why he should be disqualified from being a slave and is an important link that legitimises the children of Zilpah and Bilhah. If it could be proved by the T. Naphtali's author that Rotheos was of a noble lineage rather than one of slavery, then Rotheos' grandchildren would also be heirs of that noble lineage and unable to be described as the sons of slaves.

B. A. Pearson has suggested that the term $\epsilon \dot{v} \gamma \epsilon^{\prime} \nu \epsilon \iota \alpha$ does not simply refer to aristocratic birth, but was a technical term whose background could be found in Hellenistic Judaism. ${ }^{28}$ Unfortunately, Pearson provides little explanation and support for a suggestion he bases on only two references in Philo. If he is correct that $\epsilon \dot{v} \gamma \epsilon^{\prime} v \epsilon \iota a$ was a technical term in Hellenistic Judaism, it would be helpful to discover from where in Hellenism this concept derived and how it was applied throughout a variety of Jewish works. An appeal to just two references in a single work should not qualify $\epsilon \dot{\gamma} \gamma \epsilon \in v \epsilon \iota \alpha$ as a technical term in Hellenistic Judaism and requires, therefore, that a more comprehensive investigation be made.

\footnotetext{
27 Paul Virgil McCraken Flesher, Oxen, Women, or Citizens: Slaves in the System of the Mishnah (Atlanta: Scholars Press, 1988), pp. 95-96.

28 B. A. Pearson, The Pneumatikos-Psychikos Terminology in 1 Corinthians (SBLDS 12) (Missoula: Scholars Press, 1973), p. 43.
} 


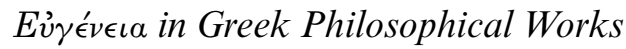

A survey of the authors available on the Thesaurus Linguae Graecae CDROM reveals approximately 1,800 occurrences of some form of $\epsilon \dot{v} \gamma \dot{\gamma} v \epsilon \iota$. A majority of these can be easily categorised as descriptions of aristocratic birth among the rich and powerful. But there are several references that may be of significance for understanding the term's appearance in Hellenistic Judaism.

In the early part of the third century C.E., Diogenes Laertius recorded that Aristotle and Metrodorus both wrote books on the idea of noble birth. ${ }^{29} \mathrm{Un}$ fortunately, however, neither document is extant. ${ }^{30}$ Diogenes does provide for us, nevertheless, what he describes as Plato's four divisions of $\epsilon \dot{\gamma} \gamma \epsilon \epsilon^{\prime} \in \iota a$ as follows: (1) those who are handsome, gentle and just are considered noble as are their descendants; (2) the descendants of princes and magistrates are noble; (3) ancestors who are illustrious through either military or national success are noble as are their descendants; and (4) those who are generous and of a high-minded spirit are noble and actually possess the highest form of nobility. ${ }^{31}$ According to Plato it is the fourth division that is best because $\epsilon \dot{v} \gamma \in \dot{\epsilon} v \epsilon a$ is not dependent upon ancestry but on one's self-worth. ${ }^{32}$

While Aristotle's book specifically on noble birth is not extant, his other works do provide some helpful insights. ${ }^{33}$ In Politics, he makes an implicit contrast between those who are $\epsilon \dot{\gamma} \gamma \epsilon \nu \eta^{\prime} s$ and those who are $\delta o \hat{v} \lambda o s$. He says it is better that those who are wealthy and possess nobility $(\epsilon \dot{v} \gamma \epsilon \dot{\epsilon} \nu \iota \alpha)$ be the ones who seek political office and rule lest the poor take office and the state consists of only slaves $(\delta o v \lambda o \iota) .{ }^{34}$ In other parts of Politics he makes it clear that he considers the $\epsilon \dot{v} \gamma \epsilon^{\prime} v \epsilon l a$ to be those who are a result of good breeding, and possessors of wealth and virtue. ${ }^{35}$ These requirements, consequently, would rule out the possibility of slaves being recognised as noble in an Aristotelian system.

In Rhetoric, Aristotle provides further insight into what he considers the basis of noble birth. By way of providing a definition he says:

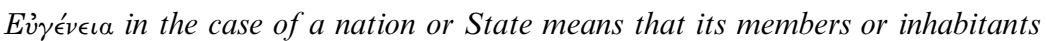
are sprung from the soil, or of long standing; that its first members were famous as leaders, and that many of their descendants have been famous for qualities that are

29 All quotes from Diogenes are taken from R. D. Hicks, Diogenes Laertius (2 vols, LCL, Cambridge, Mass.: Harvard University Press; London: W. Heinemann, 1925).

30 D. L. Biog. 5.22; 10.1.

31 D. L. Biog. 3.88-89.

32 In addition to Plato, Diogenes Laertius also records that Anisthenes taught that $\epsilon \dot{v} \gamma \epsilon \nu \epsilon \iota \alpha$ belonged to the virtuous. Virtue was a matter of deeds that could guide the wise man in public and private life and was sufficient for happiness when accompanied by the strength of Socrates (D. L. Biog. 6.11). Zeno suggested a similar explanation saying that those who desire philosophy must put away pleasure and bend their will. At this controlling of their own will they are recognised as noble and can receive virtue with instruction (D. L.Biog. 7.8). In many ways both Anisthenes' and Zeno's definition of $\epsilon \dot{\gamma} \gamma \epsilon \in \epsilon \iota \alpha$ is an elaboration of Plato's fourth division. Nobility is not always the result of one's ancestors, but of personal choice to be a person of virtue.

33 All quotes from Aristotle are taken from: Harold P. Cooke et al., Aristotle (23 vols, LCL, Cambridge, Mass.: Harvard University Press; London: W. Heinemann, 1965-1979).

34 Politics 1283a. 16.

35 Politics 1283a. 34-35; 1294a. 21; 1301b. 40. 
highly esteemed. In the case of Private individuals, $\epsilon \dot{\gamma} \gamma \epsilon \dot{v} \in \iota$ is derived from either the father's or mother's side, and on both sides there must be legitimacy; and, as in the case of a State, it means its founders were distinguished for virtue, wealth, or any of the other things that men honour, and that a number of famous persons, both men and women, young and old, belong to the family. ${ }^{36}$

In another section of Rhetoric he further elaborates saying that those who are $\epsilon \dot{\gamma} \gamma \epsilon \nu \eta \dot{s} s$ are more ambitious than others and that nobility is an inheritance from one's ancestors in conjunction with an excellence of race ( $\gamma$ évovs) that does not suffer degeneration in the family with the passage of time. ${ }^{37}$ Absent in Aristotle is the idea that a person is noble because of personal choice to be virtuous. His definition is based solely upon the status of aristocratic ancestors and the inherited benefits of lineage. ${ }^{38}$

These definitions from antiquity suggest that $\epsilon \dot{\gamma} \gamma \in \dot{v} \epsilon \iota \mathrm{l}$ was defined in two ways. The most common was to view the term as representing those who could claim to have respectable and famous ancestors known for a variety of deeds and able to pass their own prestige down to their descendants. The second, and perhaps somewhat less popular usage than the first, was to view the term as a philosophical badge of honour awarded to those who exhibited characteristics of virtue and generosity striving to put others before themselves. Based on these definitions, it is now possible to test them against some of the relevant Jewish literature.

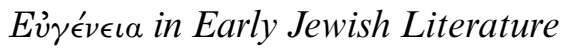

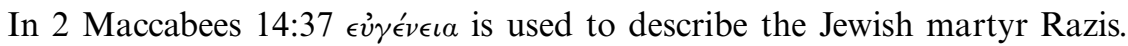
According to the passage, Razis had a reputation of good works and as a father of the Jews. ${ }^{39}$ When Nicanor sends his soldiers to capture him, Razis decided that it was better to commit suicide rather than suffer at the hand of sinners that which was contrary to his own $\epsilon \dot{\gamma} \gamma \epsilon^{\prime} v \epsilon \iota a$ (14:42). While the language of slavery is not present in the pericope, the concept of unjust captivity is implied through Nicanor's intention to seize ( $\sigma v \lambda \lambda \alpha \beta \epsilon \hat{i v})$ Razis and is pre-

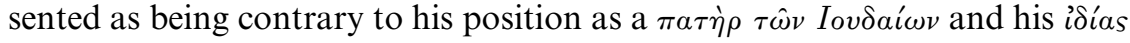
$\epsilon \dot{v} \gamma \in \nu \in i$ as.

In Fourth Maccabees language of nobility appears fourteen times and consistently in the context of maintaining obedience to the law for the sake of ancestral lineage. ${ }^{40}$ In 6:5 Eleazar is described as $\epsilon \dot{v} \gamma \epsilon \nu \eta^{\prime} s$ because of his refusal to obey the command to apostatise. In spite of the torture and pain he endured ( $\dot{\pi} \pi \dot{\epsilon} \mu \nu \epsilon, 6: 9$ ), Eleazar resolved to uphold the law and appealed to

36 Rhetoric 1.4 .5 (trans. Cooke, LCL).

37 Rhetoric 2.15.1-3.

38 Comparable to Aristotle is the comment by Dio Chrysostom (Or. 15.31): 'it is impossible for anyone to be noble ( $\gamma \epsilon \nu \nu \alpha \hat{i} o s)$ without being nobly-born $\left(\epsilon \dot{v} \gamma \epsilon \nu \eta_{s}\right)$ at the same time, or for one

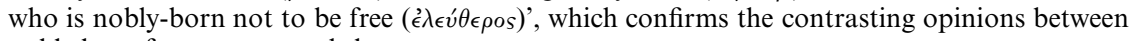
nobly born free persons and slaves.

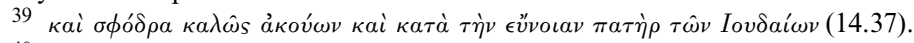

40 David A. deSilva, 'The Noble Contest: Honor, Shame, and the Rhetorical Strategy of 4 Maccabees', JSP 13 (1995), p. 37. 
others as children of Abraham not to apostatise but to accept death nobly as he does himself. ${ }^{41}$

In 8:4 the author tells us that it is obvious to those waiting to torture the seven youths that they are of noble birth $(\epsilon \dot{v} \gamma \in \dot{\epsilon} v \epsilon \iota)$. When the first son is taken to be tortured he is described as a true son of Abraham (9:21) who nobly

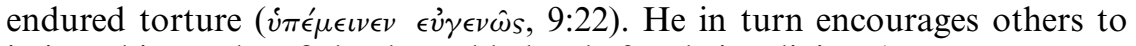
imitate him and to fight the noble battle for their religion ( $\epsilon \dot{v} \gamma \epsilon \nu \hat{\eta} \sigma \tau \rho a \tau \epsilon i a \nu$ $\sigma \tau \rho \alpha \tau \epsilon$ 'v $\sigma \alpha \sigma \theta \epsilon, 9: 24)$ with the hope of gaining the same vengance upon their enemies as was given to their fathers. He is followed by the second son who possesses a noble resolve ( $\epsilon \dot{v} \gamma \epsilon \nu \hat{\eta} \gamma \nu \omega \dot{\mu} \mu \eta \nu, 9: 27)$, the third who reflects on the importance of his lineage (10:2), and by the fourth in continuation of the noble brotherhood ( $\tau \hat{\eta} \nu \in \dot{v} \gamma \epsilon \nu \hat{\eta} \alpha \dot{\alpha} \delta \epsilon \phi \tau \eta \tau \alpha, 10: 3,15 \mathrm{~b}$ ). Language of nobility is not used to describe the rest of the brothers, but before the seventh son dies he declares that all had fulfilled their piety to God by dying nobly $(\epsilon \dot{v} \gamma \epsilon \nu \hat{\omega} s$ $\dot{a} \pi \circ \theta$ avóv $\tau \epsilon$ ), a category that he subsequently joins. Finally, the author elaborates on the fate of the youths and its significance in chapter 13 . We are told

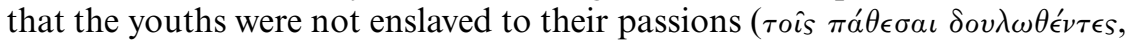
13:2) and thus able to resist the pressure of apostasy by encouraging one an-

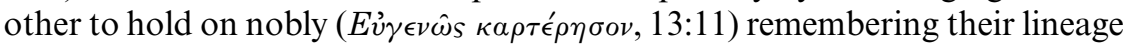

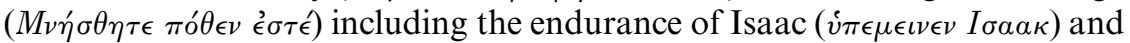
others who exhibited great courage in fulfilment of the law. ${ }^{42}$ All seven die convinced that because of the circumstances of their death, Abraham, Isaac and Jacob would receive and praise them. ${ }^{43}$

Fourth Maccabees is similar to Second Maccabees by regarding $\epsilon \dot{\gamma} \gamma \epsilon \nu \epsilon \iota \alpha$ as the result of lineage and as contrary to enslavement. Fourth Maccabees, however, is not concerned with physical enslavement, but with the type of bondage that occurs when one is mastered by passions that can lead to apostasy. Because $\epsilon \dot{\gamma} \gamma \epsilon^{\prime} v_{\epsilon \iota \alpha}$ is contrary to this type of enslavement, pain and suffering may have to be endured to remain obedient to the law. In some cases, death may not only be threatened but also accepted as the ultimate way of exhibiting solidarity with the $\epsilon \dot{v} \gamma \epsilon^{\prime} \nu \epsilon \iota a$ of Judaism's ancestors.

Philo's approach contrasts somewhat with the Maccabean literature. While the latter are concerned with $\epsilon \dot{\gamma} \gamma \epsilon \dot{v} \in \iota a$ as connected to lineage and religion, Philo's definition is closer to the philosophical badge of honour found in Plato's fourth division. In many ways Philo echoes the common sentiment among Stoics that nobility was not a matter of lineage but of a mind that had been given over to learning and wisdom. ${ }^{44}$ As a Jewish philosopher, Philo be-

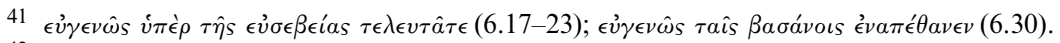

42 J. W. Van Henten has noted: 'By putting the martyrs in the framework of Jewish history and linking their actions with those of the Jewish forefathers from Abraham onwards, the author of 4 Maccabees presents a heroic image of the Jewish people. This people distinguishes itself from all other peoples not only in its unique religion and culture, but also by the fact that members of people had demonstrated their uncompromising loyalty to the Jewish traditions up to the Greek era' (The Maccabean Martyrs As Saviours of the Jewish People, Leiden: Brill, 1997, p. 243).

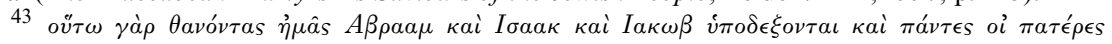

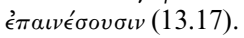

${ }^{44}$ H. A. Wolfson, 'Philo', in Foundations of Religious Philosophy in Judaism, Christianity and Islam (Cambridge: Harvard University Press, 4th rev. 1968), 2: 221; Pearson, p. 40. 
lieved that the status of $\epsilon \dot{v} \gamma \epsilon^{\prime} v \epsilon \iota$ was founded upon the premise of wisdom and love of $\mathrm{God}^{45}$ and that it was impossible for someone to claim to possess noble birth and yet neglect the performance of noble acts. ${ }^{46}$ Birth, whether noble or ignoble, did not necessarily determine the status of a person. Cain for example is one who was born of a noble man, but did not perform deeds consistent with his lineage. Abraham, on the other hand, descended from worshippers of the stars, but removed himself to follow God and became a paradigm of nobility. ${ }^{47}$ Although his lineage was ignoble, Abraham proved himself a possessor of $\epsilon \dot{\gamma} \gamma \epsilon \dot{v} \in \iota a$ through his desire to have kinship with God. ${ }^{48}$ Philo's opinion of what constitutes $\epsilon \dot{\gamma} \gamma \epsilon \in \in \iota$ is clearest, however, in his insistence that anyone who puts their trust in the noble lineage of the patriarchs but does not practice noble actions are enemies of the Jewish nation. ${ }^{49}$ This is the dangerous result, Philo believes, of a people who define their nobility by lineage instead of wisdom and love for God and think they have a license to commit ignoble acts.

Philo also believes that $\epsilon \dot{v} \gamma \in \dot{v} \in \epsilon \iota$ is contrary to slavery. However, his approach is slightly more nuanced than that of the other literature. When Hagar is offered by Sarah to Abraham she is said to be an Egyptian by birth and

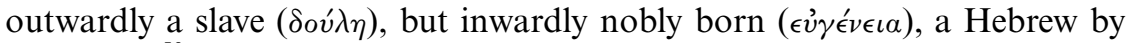
rule of life. ${ }^{50}$ Because Philo defines $\epsilon \dot{\gamma} \gamma \epsilon \in$ ve $\operatorname{co}$ in light of character, conduct, and not ancestry, Hagar is able to join the noble lineage of Abraham. Her adherence to the Jewish law made her noble therefore making nobility a reflection of inward character and not outward status. According to Philo, $\epsilon \dot{v} \gamma \epsilon^{\prime} v \epsilon \iota a$ was only a contradiction to the inward soulish type of enslavement rather than the physical kind. Anyone could be a $\delta o \hat{v} \lambda o s$ and still possess $\epsilon \hat{\gamma} \gamma \epsilon^{\prime} v \epsilon \iota a$ without contradiction.

We may conclude, then, that Pearson was correct in his assessment of $\epsilon \dot{\gamma} \gamma \epsilon \in \epsilon \iota \alpha$ as a technical term in Hellenistic Judaism. Crucial was the ability of every Jew to claim descent from famous patriarchs. By adopting the notion of $\epsilon \dot{v} \gamma \in \dot{v} v \epsilon \iota$, authors were able to present the concept of noble lineage and solidarity with the ancestors of Judaism. Because Jews were able to identify with this famous lineage, slavery, either of the body or the soul, was deemed incompatible with their status as a noble people. When presented with the possibility of enslavement two responses were possible. The martyr option counselled that those threatened with enslavement should refuse to submit even to the point of death. The philosophical option counselled that physical enslavement could be endured because nobility is not a matter of lineage, but of good works and internal qualities. One could be outwardly enslaved, but inwardly free and noble. In both cases, enslavement of either the body or the soul was perceived as contrary to the true status of a person of nobility.

45 Drunkenness 58.3; Sobriety 56.3; Congr. 56.5.

46 Spec. 4.181-82; Virtues 190, 195, 200.

47 Virtues 203, 206.

48 Virtues 218-19.

49 Virtues 226.

50 Abraham 251.2. 


\section{Lineage, Noble Birth and Slavery in Late Antiquity}

Apart from the notions of noble birth rehearsed above, there was also a wider understanding of the importance of genealogy in late antiquity. For instance, purity of descent played an important role for Jews in the Second Temple period especially for those among the priestly classes. According to Josephus, a list was maintained in the Temple which recorded the genealogical information of all priestly families including those living in the Diaspora. A special committee of priests was responsible for the maintenance and verification of all the genealogical records (Against Apion, 1.7). Descent was also important in later periods among the sages. While lineage was not usually a factor that contributed to one's position among the sages, genealogies were sometimes invented. These were not intended to demonstrate noble birth, however, but that some had overcome descent from infamous and evil gentiles (Sisera, Sennacherib, Haman, Nero) to become important teachers (i.e. Akiva, Meir and others). Similar to Philo's portrayal of Hagar, 'the evident purpose of such legends was to demonstrate that the acquisition of learning and piety was not dependent upon noble descent. ${ }^{51}$

Among some Romans lineage was seen not only as a link to power and prestige but also as contradiction to slavery. Dio Chrysostom introduced this notion in a contrived dialogue between two persons, one free the other enslaved. After a debate about the nature of slavery the enslaved individual demonstrates that all means by which slaveholders acquire slaves are illegitimate. The enslaved person bases his argument on the fact that if one traces back through a sufficient amount of a slave's generations, one would ultimately reach the point where a free person had been illegitimately reduced to slavery. The enslaved person concludes: 'For if being captured makes a man a slave, the men themselves who were captured deserve that appellation more than their descendents do; and even if it is having been born of slaves that makes men so, it is clear that by virtue of being sprung from those who were captives and were consequently freeborn, their descendents would not be slaves. ${ }^{52} \mathrm{In}$ many ways, the claims made by the enslaved person reflect what is found in T. Naphtali 1.9-12. Rotheos and his ancestors, like any enslaved individual, would not have been considered to be legitimately enslaved because their lineage was ultimately that of free persons.

Enslavement of nobly born individuals was also a popular theme in Hellenistic Romance novels. Often the plot centered on a young man or woman who had been taken as a slave and then forced to either protect himself or herself from the story's antagonist until their true identity was revealed. Often these stories have a happy ending in which the enslaved was able to regain freedom and sometimes even acquire a high position either in the antagonist's

\footnotetext{
51 Israel Moses Ta-Shma, 'Genealogy in the Second Temple Period', in Encyclopaedia Judaica, ed. Cecil Roth (Jerusalem: Keter Publishing, 1972), 7: 380-83.

52 Dio Chrysostom Or. 15.26; see also comments by Jennifer Glancy, Slavery in Early Christianity (Oxford University Press, 2002), p. 74.
} 
household or society as a whole. ${ }^{53}$

One interesting example of the contrast between noble birth and slavery is the 'Hymn of the Pearl' found in the Acts of Thomas. This Gnostic hymn tells the story of a young man, the son of a king, who is sent to Egypt to retrieve a great pearl. However, while in Egypt the young man forgets his noble birth and begins to live as a common Egyptian and becomes a slave of the king. The young man's situation is only rectified when he receives a letter from his parents which reminds him of his noble birth and allows him to reassert his true identity. ${ }^{54}$

What this evidence demonstrates is that genealogy and descent from a freeborn individual was a common concern of many in late antiquity. It is not surprising then that Jews who already placed strong emphasis on lineage would adopt the notion of noble birth as a way to counteract the stigma of slavery. The ability to trace one's lineage back to a freeborn individual was a way to remove the stigma that slavery inflicted upon its victims. The enslavement of those who could trace their lineage to a free and/or nobly born ancestor was considered to be an illegitimate act.

\section{Noble Birth as the Legitimising Factor in the Testament of Naphtali}

Returning to the case of Rotheos, in light of the above analysis it appears that the author of Greek T. Naphtali adopted the idea of $\epsilon \dot{\gamma} \gamma \epsilon \in \in \iota \alpha$ as a way to emphasise the importance of lineage. Similar to Philo and the Maccabean

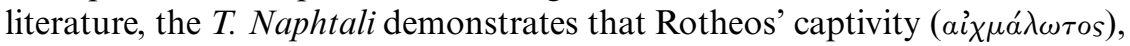
and subsequent enslavement, is inconsistent with his descent from Abraham which defines him as a possessor of $\epsilon \dot{v} \gamma \in \dot{\epsilon} v \epsilon \iota a .{ }^{55}$ In order to present the children of Zilpah and Bilhah as legitimate heirs to the Abraham-Isaac-Jacob line the notion of $\epsilon \dot{v} \gamma \epsilon^{\prime} v \epsilon \iota a$ was adopted to prove that Dan, Asher, Gad and Naphtali were able to claim a famous ancestor and that to label them as 'sons of slaves' would be inconsistent with their identification as nobly born. By manufacturing this connection to Abraham on both the father and the mothers' sides, the author guaranteed that legitimacy was a result of both parents being related to a famous ancestor and that the offspring could claim the status of $\epsilon \dot{v} \gamma \epsilon^{\prime} v \epsilon l a$ and not be branded the sons of slaves. ${ }^{56}$ While the lineage in Greek T. Naphtali does provide a Semitic ancestry for Zilpah and Bilhah, it is the contrast

53 For a discussion of these elements in Hellenistic romance novels see Glancy, p. 74; Dale Martin, Slavery as Salvation (New Haven and London: Yale University Press, 1990), p. 130.

54 Acts of Thomas 108-13.

55 A similar situation may be found in T. Joseph 14.3-4. Here the Egyptian woman's pretext for having Joseph released is that captivity is contrary to his status of nobility and that he should

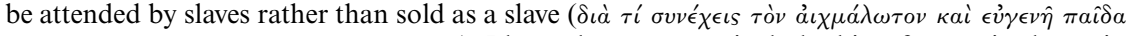

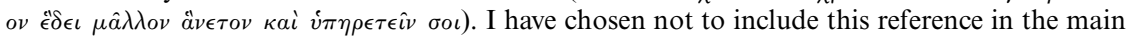
body due to the continuing debate surrounding the origin of the Testaments that makes it difficult to appeal to this passage as evidence of a Jewish tradition.

56 Louis Ginzberg similarly commented: 'The tendency of Jewish legend is to make all the tribes related to Abraham, on their paternal as well as their maternal side, and hence the statement that Rotheos was of the family of Abraham' (The Legends of the Jews, Philadelphia: Jewish Publication Society of America, 1968, 5:295). 
between slavery and noble birth that provides the author with an argument for legitimising the four brothers. Without identifying a nobly born ancestor the lineage would not be able to explain how these four patriarchs were able to claim a place in the destiny of Israel if they were vulnerable to the accusation of being the sons of slaves. 